International Journal of Agriculture, Environment and Bioresearch

Vol. 06, No. 05; 2021

ISSN: $2456-8643$

\title{
SPATIAL DISTRIBUTION OF Coelaenomenodera lameensis (COLEOPTERA: CHRYSOMELIDAE, HISPINAE), IN THE MAIN OIL PALM TREE PRODUCTION AREAS IN COTE D'IVOIRE
}

\author{
Ahou Cyprienne KOUASSI ${ }^{12^{*}}$, Akpa Alexandre Moïse AKPESSE ${ }^{1}$, N'Klo HALA $^{2}$, Assiénin Hauverset \\ N'GUESSAN ${ }^{2}$, Kouakou Hervé KOUA ${ }^{1}$ and Kouassi Philippe KOUASSI ${ }^{1}$ \\ ${ }^{1}$ University Félix Houphouët-Boigny, UFR Biosciences, Laboratory of Natural Environment and Biodiversity \\ Conservation, Abidjan, Côte d'Ivoire, 22 BP 582 Abidjan 22 Côte d'Ivoire \\ ${ }^{2}$ National Agronomic Research Center (La Mé Station), 13 BP 989 Abidjan 13 Côte d'Ivoire
}

https://doi.org/10.35410/IJAEB.2021.5677

\begin{abstract}
The oil palm tree, the first source of fatty substances of plant origin in the world, is subject to attacks from many pests. Among these, Coelaenomenodera lameensis (Coleoptera, Chrysomelidae: Hispinae) is the most serious pest of oil palm in West Africa and mainly in Côte d'Ivoire. This insect causes significant damage which greatly compromises the crops. Indeed, the fight against this pest requires knowledge of the infested areas. This study, which was conducted from September 2015 to December 2017, therefore aimed to establish spatial distribution of this pest in the main oil palm production areas. Thus, attack levels of $C$. lameensis were evaluated by counting insects every 2 months in the palm groves of 9 localities producing oil palm. The results found significant differences between localities with regard to the average index of larvae and adults. These indexes were particularly higher in the South-Central zone, the locality of Divo being the most affected with an average index of 5.22 larvae/palm and 7.32 adults/palm. Phytosanitary surveillance of palm groves in the localities surveyed, especially those of Divo, should therefore be reinforced. This requires a perfect knowledge of the biology and also evaluation of the impact of this pest on the production.
\end{abstract}

Keywords: Spatial distribution, oil palm tree, Coelaenomenodera lameensis, index, Côte d'Ivoire, areas, localities.

\section{INTRODUCTION}

Oil palm tree (Elaeis guineensis Jacq.) is cultivated mainly for oil palm and palm kernel oil (USDA, 2015) used in the manufacture of many agri-food, cosmetic and biofuel products (Ataga and Van der vossen, 2007). It is the primary source of vegetable fat on the world market (USDA, 2015). In Côte d'Ivoire, oil palm tree cultivation covers an area of approximately 300,000 ha with an annual palm oil production of 415,000 tonnes (FAO, 2015). It employs more than a million people and generates more than 400 billion CFA francs in turnover (D'Avignon, 2013). As a result, Ivorian production should continue to increase to meet the country's own needs, West African demand (Anonymous, 2015) as well as the needs of the rest of the world.

However, oil palm cultivation is subject to the ever increasing threat of numerous insect pests, the most harmful of which in West Africa and in particular in Côte d'Ivoire is the leaf miner, 
Coelaenomenodera lameensis (Coleoptera: Chrysomelidae - Hispinae) (Mariau et al., 1981; Mariau, 2001; Koua et al., 2010; Coffi et al., 2012 ; Tano, 2013 ; Akpesse et al., 2015). In the event of outbreaks, this insect can cause extremely serious damage and compromise crops for two to three years if no control or protection measures are taken (Jacquemard, 1995; Berti and Mariau, 1999).

To better understand the strategies for combating this pest, controlling the distribution of its populations in the main oil palm production areas appears to be a necessity. This is why this study aims to study the spatial distribution of $C$. lameensis, in the main oil palm production areas in Côte d'Ivoire.

\section{MATERIALS AND METHODS}

\subsection{Study localities and sites}

The study was carried out from September 2015 to December 2017 in the palm groves (plots) of 9 localities in the southern part of the Ivory Coast. These localities are divided into 3 areas: the South-East zone with the palm groves of La Mé, Eloka, Ehania, the South-Center area with the palm groves of Anguédédou, Dabou and Divo and the South-West area with the palm groves of Sassandra, Grand-Béréby and Iboké. The prospected sites belong to different agro-industries (Table 1). The south of the Côte d'Ivoire occupies $50 \%$ of the territory. It constitutes the wettest zone with more than $1500 \mathrm{~mm}$ for temperatures ranging from $29^{\circ}$ to $32{ }^{\circ} \mathrm{C}$ and includes practically the entire forest region (Anonymous, 2017).

\section{Table 1: Localities and sites according to areas}

\begin{tabular}{|cccc|}
\hline Areas & Localities & Sites & Geographical coordinates \\
\hline \multirow{4}{*}{ South-East } & La Mé & CNRA & Latitude $5^{\circ} 26^{\prime} \mathrm{N}$ Longitude $3^{\circ} 50^{\prime} \mathrm{O}$ \\
& Eloka & PALMAFRIQUE & Latitude $5^{\circ} 18^{\prime} \mathrm{N}$ Longitude $3^{\circ} 48^{\prime} \mathrm{O}$ \\
& Ehania & PALMCI & Latitude $5^{\circ} 28^{\prime} \mathrm{N}$ Longitude $3^{\circ} 12^{\prime} \mathrm{O}$ \\
\hline \multirow{5}{*}{ South-Center } & Anguédédou & PALMAFRIQUE & Latitude $5^{\circ} 24^{\prime} \mathrm{N}$ Longitude $4^{\circ} 12^{\prime} \mathrm{O}$ \\
& Dabou & CNRA & Latitude $5^{\circ} 22^{\prime} \mathrm{N}$ Longitude $4^{\circ} 08^{\prime} \mathrm{O}$ \\
& Divo & CNRA & Latitude $5^{\circ} 50^{\prime} \mathrm{N}$ Longitude $5^{\circ} 22^{\prime} \mathrm{O}$ \\
\hline \multirow{3}{*}{ South-West } & Sassandra & CNRA & Latitude $4^{\circ} 54^{\prime} \mathrm{N}$ Longitude $6^{\circ} 09^{\prime} \mathrm{O}$ \\
& Grand-Béréby & SOGB & Latitude $4^{\circ} 40^{\prime} \mathrm{N}$ Longitude $6^{\circ} 09^{\prime} \mathrm{O}$ \\
& Iboké & PALMCI & Latitude $4^{\circ} 40^{\prime} \mathrm{N}$ Longitude $7^{\circ} 24^{\prime} \mathrm{O}$ \\
\hline
\end{tabular}

CNRA: National Agronomic Research Center; PALMAFRIQUE: Palm trees of Africa, PALMCI: Palm trees of Côte d'Ivoire; SOGB: Company of Grand-Béréby rubbers

\subsection{Sampling}

Sampling on the larvae and adult populations of $C$. lameensis (Figure 1) was carried out at each of the 9 localities. Indeed, 3 plots in production of 8 ha each were chosen in each locality, that is 
to say a total of 27 plots with an age between 5 and 18 years. The density of each plot is 143 plants/ha with trees arranged in lines of 26 trees; either 5.5 lines/ha. Thus, surveys of the larval and adult populations of $C$. lameensis were carried out every 2 rows on each plot. Lines 1 and 44 of each plot were considered as border as well as trees 1 and 26 of each line. On each row, 12 trees were chosen ( 4 trees in the North, 4 trees in the Center and 4 trees in the South) so as to observe 4 palms/tree. The palms, located at a level lower than $8 \mathrm{~m}$ from the ground, are folded down with a fork to be within reach. On the other hand, those located $8 \mathrm{~m}$ or more are cut using a sickle. Thus, the external adults present on the underside of the leaflets are first counted visually to prevent them from flying away. The larvae are then counted by opening the galleries on the leaflets using forceps. This allowed the average index of adults and larvae of $C$. lameensis to be evaluated as follows:

- The average adult index (Iad): $\mathrm{Iad}=\Sigma \mathrm{ad} / \mathrm{N}$

with ad: Number of adults, $\mathrm{N}$ : Number of palms checked

- The average index of larvae (Iml): $\operatorname{Iml}=\Sigma \mathrm{La} / \mathrm{N}$

with La Number of larvae and N: Number of palms checked

- The population density of $C$. lameensis was evaluated according to the importance of the indexes according to the following criteria:

- Very low density $(\operatorname{Iad}<0.5$ or $\operatorname{Iml}<0.5)$;

- $\quad$ Low density $(0.5<\operatorname{Iad}<1$ or $0.5<\operatorname{Iml}<1)$;

- Medium density $(1<\operatorname{Iad}<5$ or $1<\operatorname{Iml}<5)$;

- High density ( $\operatorname{Iad}>5$ or $\operatorname{Iml}>5)$. 

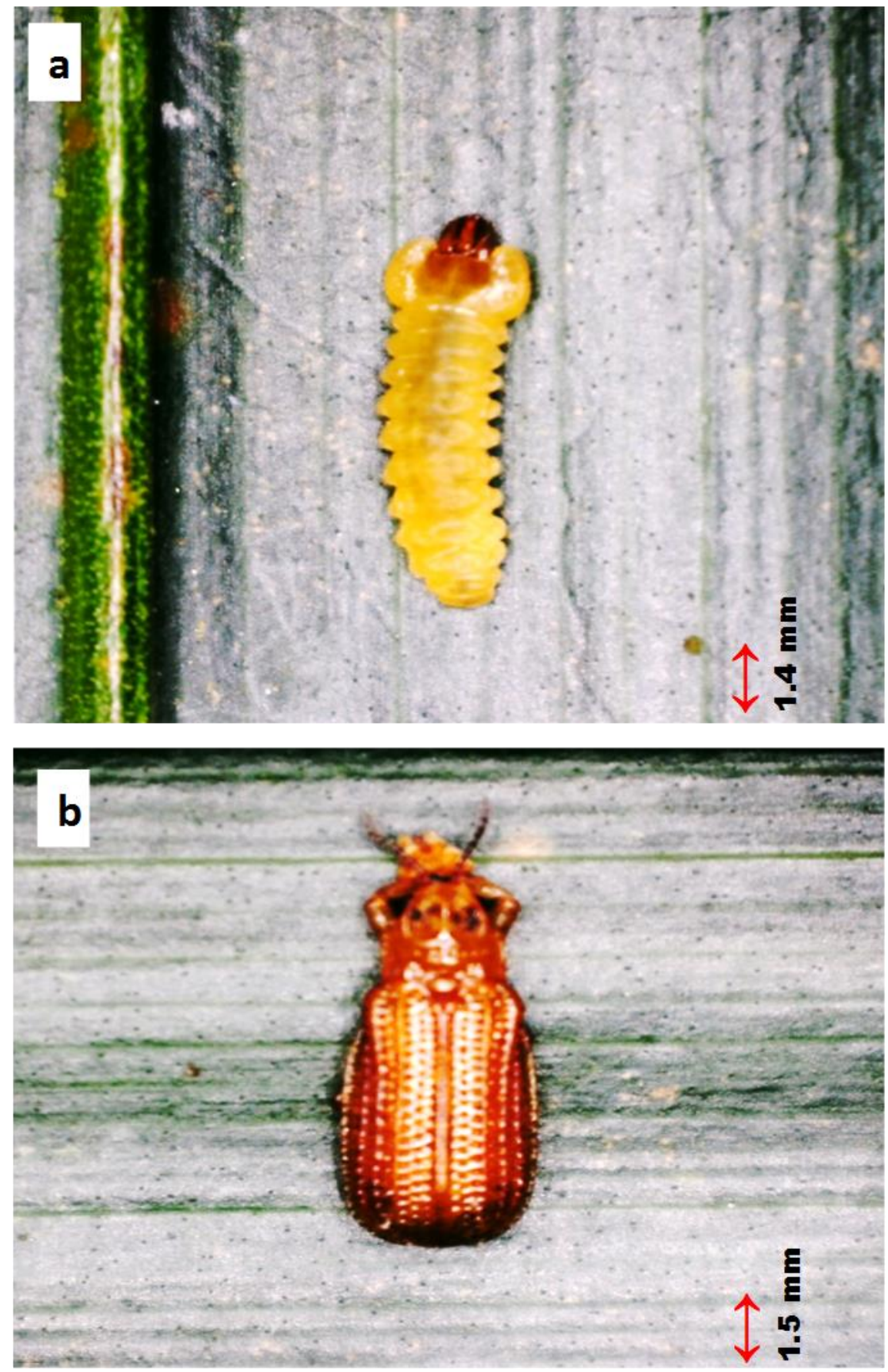

Figure 1: Larva and adult of $C$. lameensis $\mathbf{a}:$ Larva, $\mathbf{b}:$ Adult 
Vol. 06, No. 05; 2021

ISSN: $2456-8643$

\subsection{Data analysis}

Average indexes of $C$. lameensis larvae and adults were analysed for variance (ANOVA) using Statistica version 7.1 software. The Newman-keuls test carried out at the 5\% threshold made it possible to classify the means into homogeneous groups.

\section{RESULTS}

\subsection{Distribution of Coelaenomenodera lameensis in localities of oil palm production areas}

Regular monitoring of the population level of $C$. lameensis in the production areas showed a variation in the average index of this pest according to the localities.

In the South-East area, the locality of Eloka recorded the highest average index of $C$. lameensis larvae with 1.11 larva/palm against 0.87 larva/palm in La Mé and 0.39 larva/palm in Ehania. Likewise, the average adults index of $C$. lameensis was higher in Eloka with 1.31 adult $/$ palm against 0.86 adult/palm in La Mé and 0.44 adult/palm in Ehania. The average index of $C$. lameensis was therefore higher in the locality of Eloka throughout the study. Significant differences were observed between the localities with regard to the average indexes of this pest $(\mathrm{P}<0.05)$ (Table 2).

In the South-Center area, the locality of Divo recorded the highest average larvae and adults index throughout the study with respectively 5.22 larvae/palm and 7.32 adults/palm. This locality was followed by those of Anguédédou (1.28 larva/palm and 1.61 adult/palm) and Dabou (0.26 larva/palm and 0.33 adult/palm). Significant differences were observed between localities with respect to the average indexes of $C$. lameensis larvae and adults $(\mathrm{P}<0.05)$ (Table 2$)$.

In the South-West area, the locality of Sassandra recorded the highest average index larvae (1.03 larva/palm) and adults (1.02 adult/palm). This locality was followed by those of Grand-Béréby (0.44 larva/palm and 0.55 adult/palm) and Iboké with 0.23 larva/palm and 0.24 adult/palm. Significant differences $(\mathrm{P}<0.05)$ were also observed between the localities with regard to the average indexes of $C$. lameensis larvae and adults (Table 2). In general, the South-Center area was the most attacked with an average index of 2.25 larvae/palm and 3.09 adults/palm. This zone was followed by the South-East area with 0.87 adult/palm and 0.79 larva/palm and by the SouthWest area with 0.61 adult/palm and 0.57 larva/palm. Significant differences were observed between the average indexes of larvae and adults in these 3 areas $(\mathrm{P}<0.05)$ (Figure 2 and Figure $3)$.

Table 2: Average index of adults and larvae of Coelaenomenodera lameensis from localities in each production area

\begin{tabular}{|llll|}
\hline Areas & Localities & \multicolumn{2}{c|}{ Average index of $C$. lameensis } \\
\cline { 3 - 4 } & & Larvae & Adults \\
\hline \multirow{3}{*}{ South-East } & Eloka & $1.11 \pm 0.67 \mathrm{a}$ & $1.31 \pm 0.63 \mathrm{a}$ \\
& La Mé & $0.87 \pm 0.5 \mathrm{~b}$ & $0.87 \pm 0.5 \mathrm{~b}$ \\
& Ehania & $0.39 \pm 0.31 \mathrm{c}$ & $0.44 \pm 0.34 \mathrm{c}$ \\
\hline
\end{tabular}




\begin{tabular}{|llll|}
\hline \multirow{3}{*}{ South-Center } & Divo & $5.22 \pm 2.22 \mathrm{a}$ & $7.32 \pm 3.83 \mathrm{a}$ \\
& Anguédédou & $1.28 \pm 0.41 \mathrm{~b}$ & $1.61 \pm 0.8 \mathrm{~b}$ \\
& Dabou & $0.26 \pm 0.13 \mathrm{c}$ & $0.33 \pm 0.2 \mathrm{c}$ \\
\hline \multirow{3}{*}{ South-West } & Sassandra & $1.03 \pm 0.86 \mathrm{a}$ & $1.02 \pm 0.67 \mathrm{a}$ \\
& Grand-Béréby & $0.44 \pm 0.25 \mathrm{~b}$ & $0.55 \pm 0.33 \mathrm{~b}$ \\
& Iboké & $0.23 \pm 0.19 \mathrm{c}$ & $0.24 \pm 0.18 \mathrm{c}$ \\
\hline
\end{tabular}

The averages affected by the same letter in the same column are not statistically different at the $5 \%$ level.

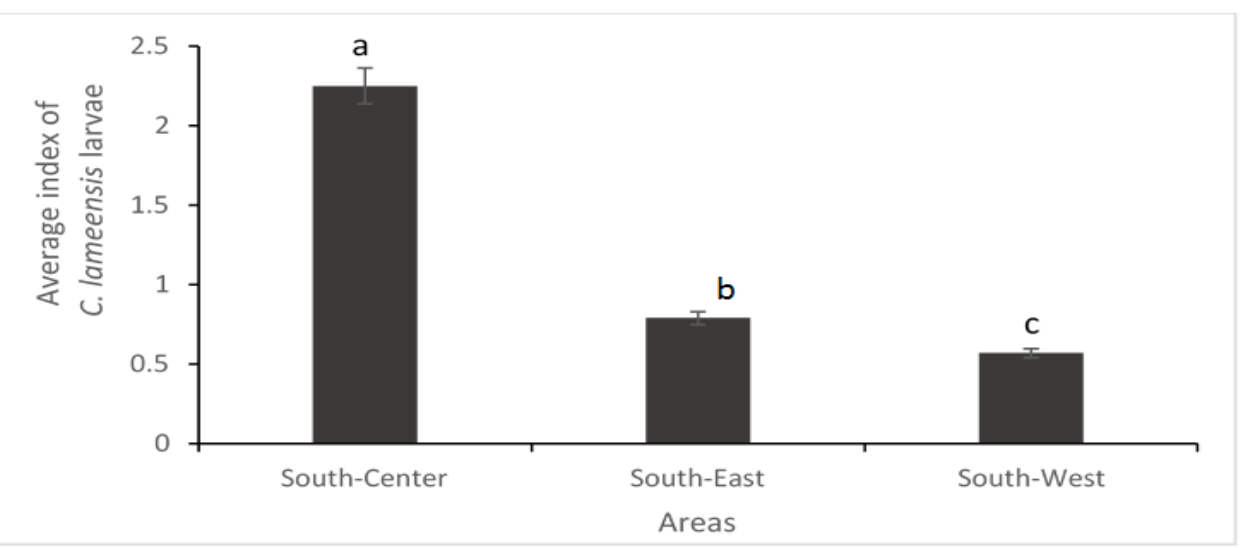

Figure 2: Distribution of the average index of $C$. lameensis larvae according to oil palm production areas

The histograms are statistically different at the 5\% threshold.

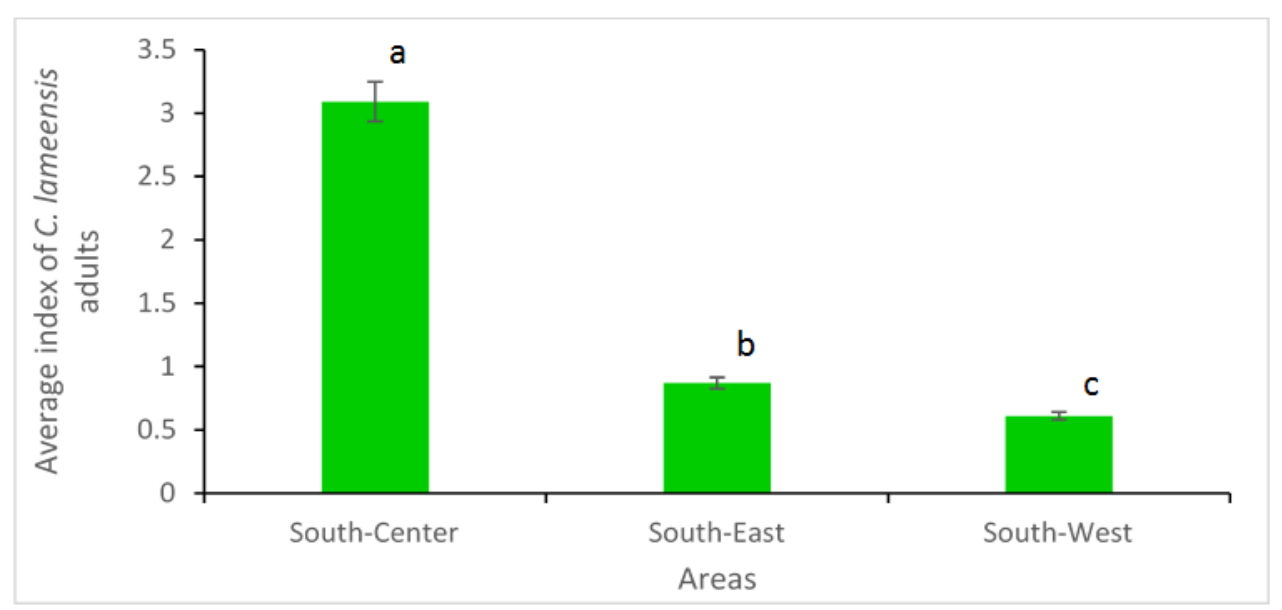

Figure 3: Distribution of the average index of $C$. lameensis adults according to oil palm production areas

The histograms are statistically different at the 5\% threshold. 
Vol. 06, No. 05; 2021

ISSN: $2456-8643$

\subsection{Mapping of areas infested by Coelaenomenodera lameensis in Côte d'Ivoire}

Regular monitoring of the level of $C$. lameensis infestation in oil palm production areas revealed the presence of the pest in all 9 localities surveyed. Thus, the localities were grouped according to the level of infestation of the larvae and adults of this pest in the palm groves.

Concerning the larvae, 3 groups of localities were observed according to their level of infestation. Thus, a high density of $C$. lameensis was observed in Divo with an average index greater than 5 larvae/palm $(\mathrm{Iml}>5)(5.22$ larvae/palm). Likewise, an medium density of $C$. lameensis larvae was observed in Eloka with 1.11 larva/palm, in Anguédédou with 1.28 larva/ palm and in Sassandra with $1.03 \mathrm{larva} / \mathrm{palm}$. For these localities, the average index of $C$. lameensis larvae is between 1 and 5 larvae/palm $(1<\mathrm{Iml}<5)$. At the locality of La Mé with an average index of 0.87 larva/palm, a low density of $C$. lameensis larvae was observed. This index is between 0.5 and 1 larva/palm $(0.5<\operatorname{Iml}<1)$. Likewise, a very low density of $C$. lameensis larvae was observed in the localities of Ehania, Dabou, Grand-Béréby and Iboké with respectively $0.39 \mathrm{larva} / \mathrm{palm}, 0.26 \mathrm{larva} / \mathrm{palm}, 0.44 \mathrm{larva} / \mathrm{palm}$ and $0.22 \mathrm{larva} / \mathrm{palm}$. In these localities, the average index of $C$. lameensis larvae is less than $0.5 \mathrm{larva} / \mathrm{palm}(\mathrm{Iml}<0.5)$ (Figure 4).

In addition, 4 groups of localities were observed according to the level of infestation with $C$. lameensis adults. Thus, a high density of $C$. lameensis was observed in the locality of Divo where an average index is recorded above 5 insects/palm $(\mathrm{Iad}>5)(7.32$ adults/palm). Likewise, an medium density of $C$. lameensis was observed in the localities of Eloka (1.31 adult/palm), Anguédédou (1.61 adult/palm) and Sassandra (1.02 adult/palm) with mean index of $C$. lameensis adults between 1 and 5 adults/palm $(1<\operatorname{Iad}<5)$. In the localities of La Mé $(0.86$ adult/palm) and Grand-Béréby $(0.55$ adult/palm), a low density of adults of $C$. lameensis was observed with an average index of adults between 0.5 and 1 adult/palm $(0.5<\mathrm{i}<1)$. A very low density of adults of $C$. lameensis was observed in Ehania with 0.44 adult $/ \mathrm{palm}$, in Dabou with 0.33 adult/palm and in Iboké with 0.24 adult/palm where the average index of adults $C$. lameensis is less than 0.5 adult/palm $(\operatorname{Iad}<0.5)($ Figure 5)

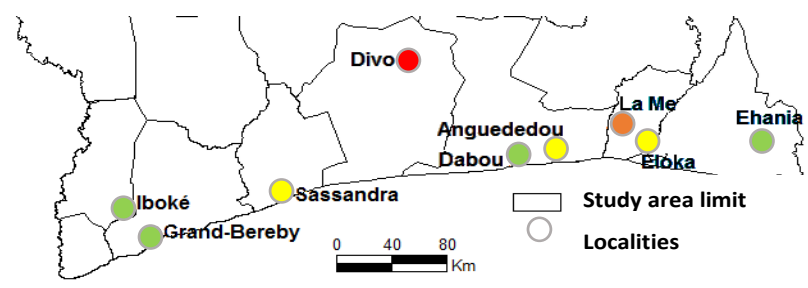

Very low density $(\operatorname{Iml}<0.5)$
Low density $(0.5<\operatorname{Iml}<1)$
Medium density $(1<\operatorname{Iml}<5)$
High density $(\operatorname{Iml}>5)$

Figure 4: Phytosanitary map of C. lameensis larvae for the period 2015-2017 
Vol. 06, No. 05; 2021

ISSN: $2456-8643$

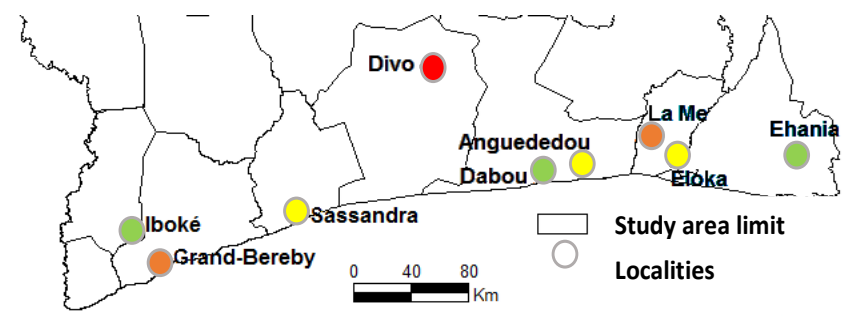

Very low density $(\operatorname{Iad}<0.5)$
Low density $(0.5<\operatorname{Iad}<1)$
Medium density $(1<\operatorname{Iad}<5)$
High density $(\operatorname{Iad}>5)$

Figure 5: Phytosanitary map of C. lameensis adults for the period 2015-2017

\section{DISCUSSION}

The study of the spatial distribution of $C$. lameensis in the oil palm production areas, showed differences between the localities with regard to the average indexes of $C$. lameensis. Indeed, a high density of $C$. lameensis was particularly observed in Eloka, Divo and Sassandra respectively in the South-East, South-Center and South-West areas. Likewise, the South-Center area with mainly the locality of Divo, was the area most attacked by this insect. These results corroborate those of Soro et al. (2020) who showed that the population densities of the 3 species of Diptera Syrphidae useful in cotton cultivation (Ischiodon aegyptius, Episyrphus balteatus, Sphaerophoria scipta) vary from one locality to another. Also, Tchetangni et al. (2019) reported that the infestation of Eteoryctis gemoniella (Lepidoptera: Gracillariidae) on cashew trees varies according to agro-ecological zones with a higher infestation in agro-ecological zone 5. These authors indicated that, this higher infestation in this area is linked to its geographical position. According to Silvie (1990), the outbreak of a species is strongly linked to the geographical location of the place considered, in the range of the species. This same observation was made by Agboton et al. (2018) in 3 cashew plantations.

Agricultural methods (systems) could be the source of variation in the population level of $C$. lameensis depending on the production areas. Since these methods can vary from one locality (or area) to another, the density of insects can also vary in the same way. During this study, we found that unlike the South-East and South-West areas, many producers in the South-Center zone do not regularly maintain their palm groves as recommended. This could be the cause of the high density of $C$. lameensis observed in this area, particularly in the locality of Divo. A similar observation was made by Soro et al. (2020) who indicated that in the Anacardium Occidentale cashew tree, the frequency and type of orchard maintenance has an impact on their health level. In fact, less than $10 \%$ of producers clean their orchards more than twice a year instead of 3 as recommended by the technical itinerary. This cultural practice would promote the proliferation of insect pests and the development of parasites in the orchard as reported by Fujinawa (2012).

The establishment of certain crops can lead to a strong proliferation of pests in the plantations. Indeed, the Lôh-Djiboua region, to which the locality of Divo belongs, is one of the main cocoa 
Vol. 06, No. 05; 2021

ISSN: $2456-8643$

production areas in Côte d'Ivoire. According to Lavabre (1977), cocoa trees are strongly attacked by many insects such as mirids, beetles (Coleoptera), etc. Coelaenomenodera lameensis being a Coleoptera, the insects of this species observed with a high density in the palm groves of Divo, could come mainly from these cocoa trees. Thus, the more the surface occupied by cocoa cultivation increases, the more the level of populations of $C$. lameensis could also increase; which can cause an imbalance of ecosystems. Pallix and Comolet (1996) indicated that the practice of extensive and shifting cocoa cultivation, combined with increasing pressure on forests or natural habitats, inevitably resulted in the degradation of natural resources linked to a profound imbalance of the natural environment.

In addition, ants of the genus Monomorium, Macromischoides and Pheidole are also predators for C. lameensis larvae (Mariau et al., 1978). On the other hand, the work of Mariau (2001) has shown that the red ants Oecophylla longinoda (Formicidae) most often attack C. lameensis larvae by destroying their ecological niche by opening galleries and adults are parasitized and killed by fungi of the genus Tichlidiopsis. All these natural enemies would therefore have influenced in a certain way the evolution of $C$. lameensis populations in the palm groves of the various localities. Thus, the natural enemies of $C$. lameensis would be absent or present with a low density on the palm groves of the localities of Eloka, Divo and Sassandra where the highest indices of $C$. lameensis were recorded. Likewise, these natural enemies would be present with a high or medium density in the palm groves of other localities having recorded the lowest indices of $C$. lameensis. There would therefore have been an imbalance between the populations of $C$. lameensis and those of its natural enemies. Indeed, Brodeur et al. (2013) reported that there may be losses of synchronism between pests and their natural enemies, which could lead to a decrease in populations of natural enemies, or even their local extinction and a decrease in biological control. This hypothesis was also supported by Moiroux et al. (2014) who indicated that the population explosion in a pest, may be related to a mismatch between this pest and its natural enemy. According to these authors, if the speed of development increases faster in the pest than in the natural enemy, when the temperature increases, then the higher the temperature will be and the greater the difference in the speed of development between the pest and its natural enemy will increase. The synchronism between the two could then be lost, with the pest being more active earlier in the season and producing more generations than its natural enemy. This interaction between natural enemies and pests was demonstrated by these authors in the apple aphid pair Aphis pomi and its parasitoid Aphidius ervi. They indicated that if the rate of development of the parasitoid Aphidius ervi decreases, then Aphis pomi will grow relatively faster than its natural enemy under global warming, creating a risk of the pest exploding. Thus, in the palm groves of Eloka (South-East area), Divo (South-Center area) and Sassandra (SouthWest area) where the population level of $C$. lameensis is higher, there would therefore have been a faster increase in the rate of development of $C$. lameensis due to an increase in temperature relative to that of its natural enemies, which would have resulted in poor regulation of $C$. lameensis populations; hence an increase of the population of $C$. lameensis in these palm groves.

The differences observed between the areas and localities surveyed with respect to the population levels of $C$. lameensis could also be linked to the effect of climatic factors (rainfall and temperature) on the insects. N'guessan et al. (2010), and Kouamé et al. (2014; 2015), reported that precipitation and temperature may be the cause of cyclical variations in cocoa mirid 
populations. Indeed, insects being ectothermic organisms, climatic factors determine both their distribution and the development of their populations over time (Pernet et al., 2014, Gagnon, 2018; Cactano, 2019). Regarding temperature, Jian et al. (2004) showed that adults of the Coleoptera Cryptolestes ferrugineus (Laemophloeidae) undergo maximum evolution at fluctuating temperatures between 30 and $36.5^{\circ} \mathrm{C}$. Soro et al. (2020), reported that the population density of Sphaerophoria scripta in cotton plots decreases with increasing temperature). According to Mariau and Lecoustre $(2000 ; 2004)$, it is on the hottest plantations that the risk of C. lameensis outbreaks is highest. During this study, the plots of Eloka, Divo and Sassandra having recorded the highest densities of $C$. lameensis were indeed the hottest. Climatic factors therefore influence insects differently as they move from one locality to another.

In addition, the variation in the population level of $C$. lameensis according to localities could be explained by the effect of insecticide treatments on the insects. In fact, insecticide treatments are generally carried out in palm groves attacked by pests. This can lead to a decrease in the population level of these pests during the period when these treatments are applied. Since the timing of application of these insecticide treatments may vary from one locality to another, the population level of $C$. lameensis may also vary from one locality to another.

\section{CONCLUSION}

The study of the spatial distribution of $C$. lameensis revealed the presence of this pest in the 3 major oil palm producing areas in Côte d'Ivoire with a high density in the South-Center area and particularly in the locality of Divo. Phytosanitary surveillance of palm groves in these areas should therefore be strengthened, with particular attention to palm groves in the locality of Divo. For this, a good knowledge of the biology of $C$. lameensis is essential, as well as an evaluation of its impact on oil palm production.

\section{Acknowledgements}

The authors express their gratitude to the National Center for Agronomic Research (CNRA) and to FIRCA (Interprofessional Fund for Research and Agricultural Council). The partnership that exists between these 2 institutions has facilitated the realization of this work, which is part of the research activities of the CNRA. The work was funded by AIPH (Interprofessional Association of the Oil palm Sector) through FIRCA.

\section{Conflict of interest}

The authors express no conflict of interest.

\section{REFERENCES}

Agboton, C., Onzo, A., Akohou, H., Goergen, G., Vidal, S. \& Tamò, M., 2018. Population dynamics of the cashew leafminer, Eteoryctis gemoniella (Lepidoptera: Gracillariidae), and inventory of its parasitoids in cashew orchards of Northern Benin, West Africa. International Journal of Tropical Insect Science, 38: 132- 144.

Akpesse A.A.M., Koua H.K., Mora P. \& Miambi E., 2015.- Enzyme profile of the oil palm (Elaeis guineensis Jacq) pest Coelaenomenodera lameensis Berti and Mariau (Coleoptera: 
Vol. 06, No. 05; 2021

ISSN: $2456-8643$

Chrysomelidae, Hispinae) according to the different developpement stages. Journal of Oil palm Research, 27 (2) : 135-143.

Anonymous, 2015 - Les politiques agricoles à travers le monde : quelques exemples. Ministère de l'agriculture, de l'agroalimentaire et de la forêt. République française. Consulté le 13 Septembre 2016. http://agriculture.gouv.fr/politiques-agricoles-fiches-pays

Anonyme, 2017 - Ville et village de Côte d'Ivoire-Grand-Bereby. www.rezoivoire.net consulté le $15 / 08 / 17$.

Ataga C.D. \& Van Der Vossen H.A.M., 2007 - Elaeis guineensis Jacq. [Internet] Fiche de Protabase. In : Van Der Vossen H.A.M. et Mkamilo G.S. (Editeurs). PROTA (Plant Ressources of Tropical Africa / Ressources végétales de l'Afrique tropicale), Wageningen, Pays-Bas. Consulté le 10 juin 2013. www.protabse.org

Berti N. \& Mariau D. 1999.- Coelaenomenodera lameensis n.sp. (Coleoptera : Chrysomelidae : Hispinae) ravageur du palmier à huile. Nouvelle Revue d'Entomologie, 16 (3) : 253-267.

Brodeur J., Boivin G., Bourgeois G., Cloutier C., Doyon J., Grenier P. \& Gagnon A-Ė., 2013.Impact des changements climatiques sur le synchronisme entre les ravageurs et leurs ennemis naturels : conséquences sur la lutte biologique en milieu agricole au Québec. Rapport final, 99 p.

Cactano J., 2019. Impacts du changement climatique sur le développement et sur la préférence du site d'oviposition du syrphe ceinturé (Episyrphus balteatus (De Geer). Mémoire de Master en biologie des organismes et écologie, à finalité approfondie. Université de Gembloux. Faculté des sciences, $63 \mathrm{p}$.

Coffi A., Philippe R., Zanou B.E.T. \& Glitho I., 2012 - Efficacité des composés métabolites secondaires extraits des folioles du palmier à huile contre les larves de la mineuse des feuilles, Coelaenomenodera lameensis (Coleoptera : Chrysomelidae). Bulletin de la Recherche Agronomique du Bénin : 56-65

D'Avignon S., 2013.- Premier congrès Africain de l'huile de palme à Abidjan : Synergie d'une filière à fort potentiel. Côte d'Ivoire Economie, Business et Finance, 25, 14 p.

Fujinawa F. M., Nadson D. C. P., Carmo E. S. D. S., Antonio D. G. \& Helson M. M. D. V., 2012. First report of Lasiodiplodia theobromae causing stem rot disease of begonia (Begonia $\mathrm{x}$ elatior hort.) in Brazil. Australasian Plant Pathology, 7 :163-166.

Gagnon A-E., Roy M. \& Roy A., 2018. Impacts directs et indirects des changements climatiques sur les ennemis des cultures. Document de synthèse, 80p.

Jacquemard J.C., 1995.- Le palmier à huile. Le technicien de l'agriculture tropicale. Edition Maisonneuve et Larose, Paris France, 207 p.

Jian F., Jayas D.S. \& White N.D.G., 2004.- Movement and distribution of adult rusty grain beetle, Cryptolestes ferrugineus (Coleoptera : Laemophloeidae), in stored wheat in response to different temperature gradients and insect densities. Journal of Economic Entomology, 97(3): $1148-1158$.

Koua K.H., Mathieu J., Seri-Kouassi P.B., Tano Y. \& Mora P., 2010.- Spatio-temporal distribution of the infestations of Coelaenomenodera lameensis Berti and Mariau (Coleoptera, 
Vol. 06, No. 05; 2021

ISSN: $2456-8643$

Chrysomelidae) an oil palm tree (Elaeis guineensis Jacq.) pest in Toumanguié (Côte d'Ivoire). Sciences et Nature, 7 (1) : 1-10.

Kouamé N.N., N'Guessan K.F, N'Guessan A.H, N'Guessan W.P. \& Tano Y., 2015. Variations saisonnières des populations de mirides du cacaoyer dans la région du Haut- Sassandra en Côte d'Ivoire. Journal of Animal and Plant Sciences, 25 (1) : 3787-3798.

Kouamé N.N., N'Guessan K.F., N'Guessan A.H., N'Guessan W.P. \& Tano Y., 2014 - Variations saisonnières des populations de mirides du cacaoyer dans la région de l'Indénié-Djuablin en Côte d'Ivoire. Journal of Applied Biosciences, 83 : 7595-7605.

Lavabre E.M., 1977.- Systématique des Mirides. In : Mirides du cacaoyer. Institut Français du Café et du Cacao, Ed., G.-P. Maisonneuve et Larose, Paris, pp 47-70.

Mariau D. \& Lecoustre R., 2000.- Rôle des facteurs éco-climatiques et édaphiques sur la fécondité au champ de Coelaenomenadera lameensis, mineur des feuilles de Palmier à huile en Afrique de l'Ouest. Insect Science and Its Application, 20 (1): 7-21.

Mariau D. \& Lecoustre R., 2004.- An explanation for outbreaks of Coelaenomenodera lameensis Berti and Mariau (Coleoptera: Chrysomelidae), a leaf minor of oil palm (Elaeis guineensis Jacq.) in West Africa, based on a study of mortality factors. Internationnal Journal of Tropical Insect Science, 24 (2) : 159-169.

Mariau D., 1988 - The parasitoids of hispidae in Biology of chrysomelidae. In: Jolivet P., Petitpierre E., et Siao T.H.H. (eds) biology of chrysomelidae. Dordrecht : Kluwer Academic Publicher, 449-461.

Mariau D., 1999.- Les coléoptères Chrysomelidae inféodés au palmier à huile et au cocotier, et leurs parasitoïdes. Annale de la société Entomologique de France, 16 (3) : 230-237.

Mariau D., 2001.- Gestion des populations de Coelaenomenodera lameensis Berti et Mariau (Coleoptera, Chrysomelidae) en vue de la mise au point d'une stratégie de lutte raisonnée. Thèse de Doctorat, Ecole Nationale Supérieure d'Agronomie de Montpellier (France), 198 p.

Mariau D., Desmier De Chenon R. \& Julia J.F., 1981 - Les ravageurs du palmier à huile et du cocotier en Afrique occidentale. Oléagineux, $36: 169-228$.

Mariau D., Phillipe R. \& Lecoustre R., 1978.- Les parasites larvaires de Coelaenomenodera elaeidis Mlk., Hispine du Palmier à huile en Afrique occidentale. Introduction à une méthode de lutte biologique. Oléagineux, 33 (4) :153-160.

Moiroux J., Bourgeois G., Boivin G. \& Brodeur J., 2014.- Impact différentiel du réchauffement climatique sur les insectes ravageurs des cultures et leurs ennemis naturels : Implications en agriculture. Feuillet technique Ouranos Projet 550005-103, Québec, Canada, 12 p.

N'Guessan A.H., N'Guessan K.F., Kouassi K.P., Kouamé N.N. \& N'Guessan P.W., 2014 Dynamique des populations du foreur des tiges du cacaoyer, Elophonotus myrmeleon Felder (Lepidoptère : Cossidae) dans la région du Haut-Sassandra en Côte d'Ivoire. Journal of Applied Biosciences, 83: 7606-7614. 
N'Guessan K.F, Kébé I.B. \& Adiko A., 2010 - Seasonal variations of the population of Eulophonotus myrmeleon Felder (Lepidoptera: Cossidae) in the Sud-Bandama region of Côte d'Ivoire. Journal of Applied Biosciences, 35 : 2251-2259.

Pallix G. \& Comolet A., 1996.- L'impact environnemental des pratiques macro-économiques d'ajustement structurel en Côte d'Ivoire. Rapport pour la Banque mondiale et le Ministère Français de la coopération, Nairobi, Kenya, 377 p.

Pernet L., 2014. Stratégies de régulation et d'optimisation thermique chez les insectes. Rapport bibliographique, 21p.

Silvie P., 1990. Syllepte derogata (Fabricius, 1775) (Lepidoptera, Pyraloïdea, Crambidae, Spilomeiinae). Coton et Fibres Tropicales, 45 (3) : 199-227.

Soro L., Soro S., Yoboué N.L., Ochou G.O 2., Menozzi P. \& Fondio D., 2020. Influence du contexte spatial et quelques facteurs climatiques sur la dynamique de trois espèces de Syrphidae (Insecta : Diptera) du cotonnier Gossypium hirsutum L. dans la région du Tchologo en Côte d'Ivoire. Journal of Animal and Plant Sciences, 45 (3) : 8038-8052

Soro S., Sanogo S.O., Gniré M., Nakpalo K.D. \& Kouadio Y.J., 2020. Analyse descriptive et facteurs agronomiques d'avant-garde de l'état sanitaire des vergers anacardiers (Anacardium occidentale L.) en Côte d'Ivoire. European Scientific Journal, 16 (30) : 72-86.

Tano D.K.C., 2013.- Contrôle des populations de Coelaenomenodera lameensis (Coleoptera: Chrysomelidae), principal ravageur du palmier à huile (Elaeis guineensis) aux moyens du Suneem 1\% EC et d'extraits de plantes locales de Côte d'Ivoire. Thèse de Doctorat, Université Felix Houphouët-Boigny, Côte-d'Ivoire, 139 p.

Tchetangni Y.A., Afouda L.C.A. \& Ouinsavi C.A.I.N., 2019. Evaluation des dégâts de Eteoryctis gemoniella (Lepidoptera:Gracillariidae) dans les plantations d'anacardier au Bénin. European Scientific Journal, 15 (12): 286-299.

USDA, 2015.- Oilseeds: World Markets and Trade. United States Departement of Agriculture. Foreign Agricultural Service. Office of Global Analysis, 38 p. 